\title{
Pastoral power and governmentality: from therapy to self help
}

\section{Abstract}

An examination of the practice of self-examination in Scottish Presbyterianism shows the value of following the later Foucault in the examination of religion as a social practice. His attention to the influence of pastoral power on governmentality is shown to have been embedded in a Roman Catholic heritage leading to a stress on the confessional. By contrast, an examination of one aspect of Protestant pastoral power indicates the genealogy of practices of self-help. An historical examination of both the structure of the Scottish church and the diaries of believers indicates the emphasis placed in this tradition on accountability. This focus then influenced developments in the United States; attention to this tradition opens up questions for contemporary practices.

Keywords: governmentality; religion; social practice; Foucault; pastoral power

Those examining the centrality of conceptions of accountability in contemporary society have drawn on the later work of Foucault's career, especially as outlined in the publication of his lectures (Millar and Rose, 2008; Mennicken and Miller, 2014). A key theme he developed was that of "governmentality", the means by which mass populations came to be governed. In doing so, he drew attention to the importance of examining particular practices of accountability. In sketching these, Foucault drew in particular on the notion of "pastoral power", arguing that specific practices within Christianity were of importance in providing templates for governing conduct in other spheres (Foucault, 2009: 123). Notably, he paid particular and detailed attention to the rite of confession, tracing how this entailed the development of particular artefacts, such as the confessional box, and the formulation of 
detailed guidance for the interrogation of the faithful (Foucault, 1999: 171-191). Catriona Macleod and Kevin Durrheim (2002) draw attention to pastoral power in their discussion of Foucault and feminism, although it is noticeable that they do not differentiate between different forms of that power within Christianity. That is, what has not been pursued in any detail are the hints that Foucault left that his examination of pastoral power was an incomplete one. Specifically, it was confined to one branch of the Christian tradition, that of Roman Catholicism. Despite some awareness of the need to examine the nature of Protestant pastoral power, the project was never completed. This article attempts to sketch in one important aspect of that tradition, the practice of self-examination, but why might this be important? In an examination of the formation of the early modern state, Philip Gorski (2005) has used Foucault's focus on religion as social practice to argue that Calvinism was a vital component of the disciplinary revolution. Through a detailed examination of practice in the early seventeenth century Netherlands, he demonstrates how Calvinism "propagated new ethics and practices of self-discipline" (Gorski, 2005: 20). He uses this to return to Foucault's work and suggest that

one would expect a brief overview of the various disciplinary mechanisms invented by Protestant and Catholic religious reformers and of the ways in which territorial rulers utilized them as part of their strategies of domination. But, instead, Foucault launches into a lengthy discussion of Machiavelli's Prince and the various treatises written in reaction to it from the late sixteenth century onwards.... On the concrete social mechanisms through which this power operated, the central concern of so much of his work, Foucault is strangely silent (Gorski, 2005: 24).

He goes to speculate that perhaps this was because to examine these concrete social mechanisms would place the origins of the disciplinary revolution in other times and places 
than he had posited (that is, it would move from eighteenth century France to seventeenth century Netherlands).

Such an approach has echoes, of course, of Weber's (1976) famous and much contested "Protestant ethic" thesis. Foucault's focus, as we will see, on religion as a social practice, rather than as belief system or institution, has the potential to suggest a different genealogy of the influence of Protestantism on some later phenomena. It points to some rather neglected hints in Weber about religious practice, specifically the practices associated with "closed" communion in Reformed Protestantism (of which more later) (Mutch, 2009). In particular, this article argues that these practices form an important context for the development of notions of "self-help". As Gabriel Abend has observed in his review of the American business ethics literature, "Its style and tone resemble those of self-help or self-improvement literature, which gives advice on what to do and how to live, harking back to Samuel Smiles's 1859 best seller, Self-Help" (Abend, 2014: 79). Smiles, as we will see, has to be seen in the context of practices associated with a particular Protestant tradition, that of Scottish Presbyterianism. Interrogating Foucault's conception of pastoral power through the experience of this tradition suggests productive ways of tracing the genealogy of self-help.

I make such suggestions by means of a detailed examination of one aspect of Protestant pastoral power in one specific location, practices of self-examination through diary keeping in Scotland across the seventeenth, eighteenth and nineteenth centuries. Just as with Foucault's tracing of the evolution of the confessional, a more detailed examination of history enables us to see some of the nuances of practices, in this case of the fostering of accountability through self-examination (Barrett, 2008: 522). The discussion starts by reviewing what Foucault said about the nature of pastoral power, with a particular emphasis on the hints about Protestant pastoral power. It then uses some of his work on the formation of subjectivity in classical antiquity to draw attention to some intriguing parallels in the work 
of one Scottish divine. This work points to the importance of accounting for the self in the Reformed Protestant tradition. The main body of the article examines this practice through the examination of diary keeping. This is recognised as only one strand, albeit an important one, of Protestant pastoral power and some implications are drawn for later technologies of subjectivity. In particular, connections with contemporary self-help manuals are drawn to indicate why it is important to extend our understanding of governmentality in the context of different forms of pastoral power.

\section{Foucault and pastoral power}

From an examination of the confessional in the context of the history of sexuality, Foucault moved to a more general consideration of the ways in which attempts to govern the conduct of populations had their origins, first, in the pre-Christian East and then in the Christian East. This was characterised within Christianity, he argued, by the consolidation within the Christian church of "precise mechanisms" that constituted "a pastoral power that was both specific and autonomous" (Foucault, 2009: 129). He continued that

it seems to me that the history of the pastorate has never really been undertaken. The history of ecclesiastical institutions has been written. The history of religious doctrines, beliefs, and representations has been written. There have also been attempts to produce the history of real religious practices, namely, when people confessed, took communion, and so on. But it seems to me that the history of the techniques employed, of the reflections on these pastoral techniques, of their development, application, and successive refinements, the history of the different types of analysis and knowledge linked to the exercise of pastoral power, has never really been undertaken (Foucault, 2009: 150). 
Foucault then goes on to sketch some features of the history of the pastorate, but, as Gorski notes, these were left undeveloped, with subsequent lectures exploring classical antiquity (Foucault 2005). As we will see, even here there were clues that can be linked to versions of Protestantism. For now, however, we can collect some of the scattered references to Protestantism that Foucault makes.

Foucault himself was well aware that his perspective was shaped by his Catholic background. He noted, for example, in an interview that, "I think any child who has been educated in a Catholic milieu just before or during the Second World War had the experience that there were many different ways of speaking as well as many forms of silence" (Foucault, 1997: 121). As Carrette observes, "By drawing out the religious nature of Foucault's earlier work I am seeking to rescue a certain unconscious dimension of his knowledge - his unashamedly Christian, and more specifically Catholic, cultural inheritance" (Carrette, 2000: 21). This inheritance means that considerable emphasis is placed on practices, notably auricular confession, that were firmly rejected by the Protestant tradition. It is not that Foucault does not recognise that Protestantism did not entail different techniques for the governance of conduct, but that these are not followed through. So, for example, at one point in his discussion he notes in parentheses, "I leave to one side the problems of Protestant countries; we will come back to them shortly from another angle" (Foucault 1999: 177). In another place we find a reference to aspects of the Protestant Reformation, "whose history, what's more, it would be very interesting to trace" (Foucault, 2009: 228). As we have seen, these promissory notes are never honoured, but there are some hints of what their investigation might entail. One aspect that Foucault notes is the difference in organizational form. So we have

On the one hand there was the, let's say, Protestant type, or the type developed by different Protestant sects, with a meticulous pastorate, but one that was all the more 
meticulous as it was hierarchically supple, and on the other hand, there was the Counter Reformation with a pastorate entirely brought back under control, a hierarchized pyramid, within a strongly centralized Catholic Church (Foucault, 2009: 149).

Within these more fluid structures, whose constitution we will consider later, there was also a focus on both public discipline and on internal self-examination. Foucault refers to English Puritanism as a site for, "the practice of permanent autobiography in which each individual recounts his own life to himself and to others, to those close to him and the people of his own community, in order to detect the signs of divine election within this life" (Foucault 1999: 184). Although Foucault's discussion of this is under-developed and in places contradictory, he does suggest that these Protestant practices did not involve a weakening of the grasp of the pastorate, rather a change in its form and practices.

This is important when we consider one attempt to apply Foucault's ideas in the context of accounting as a specific technique. In his examination of the development of double entry bookkeeping in Catholic Italy, James Aho (2005) provides a persuasive account which sees it not as a technical response to the demands of nascent capitalism but as a commitment to moral community. Set in the context of the development of penitential confession, DEB makes sense, argues Aho, as a form of justification of the activities of merchants, in which the focus is on accurate and complete accounting for conduct. What is unfortunate is that, having argued clearly that it is misleading to draw conclusions about lay practice from theological treatises, Aho then appears to rest on just such treatises for his understanding of Protestant practices. He suggests that Catholic practices of accountability were desacralized by their translation through the eyes of Dutch Calvinism into techniques for profit maximisation so that 
the business endeavors of the Calvinist were liberated from churchly moral encumbrances. Any anxiety that these endeavors might result in the merchant's damnation evaporated. (In Calvinism, man is already dammed; nothing he does or fails to do can ever change this. An elite few are predestined for salvation.) Instead, he could pursue his monetary interests with no other concern than the "bottom line" (Aho, 2005: 91).

Any encounter with the diaries of committed Protestant merchants would disconfirm this assertion. Matthew Kadane (2013), for example, has examined the diary of the devout early eighteenth century clothier and Dissenting Protestant from Leeds, Joseph Ryder. At the heart of his diary is the tension between following the injunction to avoid sloth and the perils of the worldly riches which hard work might accumulate. As Kadane observes of Max Weber's work on religion, "Probably because he considered ordinary people only in the abstract, he inadequately accounted for the psychic anguish wrought by double-mindedness" (Kadane, 2013: 91). We could apply the same stricture to Aho's work, as it accords too much weight to formal theological positions rather than following Foucault's injunction to examine religion as a social practice. When we do so we find that significant moral tensions remained for the committed Protestant which ensued in specific practices, notably those of self-examination and diary keeping. In order to examine these in more detail we need to specify more clearly the specific context we are examining.

\section{Varieties of Protestant pastoral power}

Part of the reason for this is the fissiparous tendencies of Protestantism. Roman Catholicism, of course was not itself a homogeneous tradition, but at least it had the formal unity of the church hierarchy (Chatellier 1989: 88). By contrast, three major distinct traditions can be discerned within early Protestantism (discounting, for now, the later splintering into many different sects). In his comprehensive history of the reformation, MacCulloch (2004) 
identifies these as Episcopalianism, Lutheranism and Reformed Protestantism.

Episcopalianism originates in the peculiar circumstances of England, where specific political conjunctures resulted in a very distinctive organizational and theological tradition which was later spread with the success of British imperial endeavours. Lutheranism, the cradle of the original revolt against the Catholic church, was strong in the German states and parts of Northern Europe. Its major rival was associated with the figure of Calvin and is the tradition broadly known as Reformed Protestantism. Associated with Geneva and the Netherlands, its most complete instantiation was in Scotland, where a particular conjuncture of factors enabled it to become established as the national church (Ryrie, 2006). Scotland is the focus for the rest of this article for two reasons. One is that its version of Reformed Protestantism, in the guise of Presbyterianism, was the most complete in Europe and so it provides us with an excellent source of material. The second is that the Presbyterianism it developed was particularly influential in the United States of America. In this way the techniques that it developed for the monitoring of conduct and the formation of subjectivity had a much broader impact that if they had been confined to one small country on the margins of Europe.

It is useful to give a brief sketch of some of the distinctive features of this church. Its early leaders drew on Calvin to affirm the importance of an organized church. Over a number of years it formulated the institution of the presbytery, a body consisting of the ministers (that is, the clerical incumbents) from a group of parishes, together with selected "elders". These elders were ordained members of local "sessions", a body of between six and fifteen men (they were always men) who, with their minister as their "moderator" or chair, governed the affairs of the parish. They have been particularly associated with the exercise of public discipline over those who sinned against the doctrines of the church. As MacCulloch (2004: 597) points out, "in France, the Netherlands or Scotland, the elder was concerned much more than the medieval confessor with sins that could be defined as public rather than private: 
matters which affected the community as a whole, rather than the inner thoughts of the heart". This, then, was one feature which differentiated the pastoral power of Reformed Protestantism from the Catholicism which Foucault examined. It needs to be noted as one important dimension of that power, although it is not the focus of this article. Another important distinction was the expansion of the ranks of the pastorate to encompass a small number of the committed faithful. As they were formally ordained to serve alongside the minister it is not strictly accurate to label elders as "lay", but this label does serve to indicate that their prime activities lay in the secular world. Their activities as a session were subject to monitoring by the presbytery, which would meet each month to consider local policy and discipline. From their number were selected representatives for the biannual regional meetings known as "synods" and for the annual General Assembly, held in Edinburgh. This was the church's legislative body which debated and formulated policy. However, it lacked a clearly defined executive function and the whole system has been described as a "conciliar" one rather than a traditional hierarchy (Weatherhead, 1997: 37). This organizational context is important for understanding the context in which the faithful engaged in practices of selfexamination. In order to introduce this, we now look at one particular figure in the church whose work intriguingly contradicts aspects of both Aho and Foucault, suggesting why this particular tradition deserves our attention when we consider accountability.

The Reverend James Clark served in three parishes on the east coast of Scotland before moving to the Tron Kirk in Glasgow in 1702 (Scott, 1920: 474). The son of an Edinburgh merchant, he married the daughter of another merchant. Before being ordained he "had occasion in my Younger years to be bred at Holland in Merchant Accounts, Book-keeping and other parts of the Theorie of Merchandizing, with a design at that time to have followed this kind of Institution of Life" (Clark, 1703: vii). In the turbulent religious tensions of the late seventeenth century many committed Presbyterians had spent time in exile in the 
Netherlands and it appears that during such a period Clark practised what he learned. As he recalled "in the Practick part whereanent also, I have sometimes been employed where I had not access (through the injuries and unsettlement of the late times) to follow my more free and earnest Inclinations to the Ministry" (Clark, 1703: vii). This gave him the credibility to address the thriving merchant community in Glasgow, one which had particular ties to the Netherlands, especially in a remarkable set of sermons which he published as The Spiritual Merchant: or, the Art of Merchandizing Spiritualized (Clark, 1703). Dedicated to the leading members of the town council, it explicitly drew the connections between the forms of accounting that its members would have been familiar with as merchants and the need for moral accountability. He specifically notes the connection with DEB which would have been mediated through Dutch exemplars:

Ye must be skillfull in Arithmetick and Merchants accounts book-keeping, this is so very needful that a man cannot be a compleat Merchants or manage Trade to any good effect without it, and therrefore you will find that in all great Towns of Traffique, there are schoolls and Masters for this purpose, to teach Italian Book-keeping, as it is ordinarliy termed, whereby goods, sums of money in Cash or Bank, debts to or from any, yea a man's whole stock \& moveables, are distinctly \& oredrely posted or classed in their several pages or paragraphs, so that with the greater ease, celeritie and convenience (having the help of an Alphabetick calendar) he may take a view and survey of the state of his affairs, which is both pleasant $\&$ profitable, therefore Merchants have their memorial or Wast-book, their Journal, their Leger \&c (Clark, 1703: 104).

This example was then used to suggest the need for similar practices of recording of moral practice. So, “Our Spiritual Merchant hath his Debt book or Book of Conscience, wherein he sets in order all his sins against God, committed such a day, on such an occasion, at such a 
place, with such companie \&c which exactness will mightily help you in your penitential exercises, speciallie in confessing of sins \& clearing Counts with God" (Clark 1703: 105). These books were to be kept for a purpose: "Frequentlie look into your Count-books, \& take a survey of the state of your affairs, examine your own selves, prove your own selves" (Clark, 1703: 149). Just as the careful merchant kept books of account which were regularly inspected so that they would know their position at any time, so the committed Christian should keep records to facilitate the vital practice of self-examination. Clark's work suggests the importance of self-examination in a way which is continued by later writers in the Scottish tradition. Indeed, books on the importance of self-examination, especially in the context of preparation for the sacrament of Communion, became an established genre.

To understand this genre one needs to be aware of the particular status of communion as a sacrament in Reformed Protestantism (Schmidt, 2001). As a tradition, it is generally associated with preaching rather than with ritual, but the Scottish communion "season" developed into a highly charged ritual which was an important template for North American revivalism. As compared to practice in other traditions, Scottish communion was a "closed" sacrament, that is, it was only available to those who passed tests of knowledge and behaviour. It was thus a rare event, generally only held once a year in most parishes in our period. This meant that admission to it acquired particular significance for the faithful, requiring extensive preparation for participation, something noted in passing by Weber in his essay on sects (Gerth and Mills 1948: 312). The faithful needed to feel worthy and this required techniques of self-examination. It was in this context that the Reverend William Trail, minister of Benholm, prepared in 1737 his, Some brief rules and directions concerning the great duty of self-examination both before and after the Sacrament of the Lord's supper. Published for a help to those of weaker capacities in the management of that duty. Of 45 pages in a pocket book format, this was designed for such, "as have little Money to buy, or 
little Time to read larger and better Books" (Trail, 1737: 2). Trail recognised that he could have cited Scriptural sources for his precepts (something of great weight to committed adherents) but had he done so it would have, "raised the Price, that the poorer sort, for whom it was chiefly design"d, could not so easily procured a copy: Whereas, if they have their Bibles by them, they may look to the Citations, if they do not remember the Words" (Trail, 1737: 3). This gives an indication of a broad literate audience for his work, something supported by other studies of churchgoers in the eighteenth century (when Scotland enjoyed higher rates of literacy than those obtaining in most European countries) (Smout, 1982, 127). Trail exhorted his readers to, "Learn to keep your Eye upon your Heart ordinarily and habitually, and be looking to the Frame of your Heart daily in ordinary Reading, Prayer, or other Duties, whether publick, private or secret, and take a short View after every Duty, how it has been with you in it; this will help to make stated Self-examination more easy" (Trail, 1737: 5). Many of his readers might have been more capable of reading his work than of writing a diary, but for those who had that capacity, the diary was an important aid to selfexamination.

\section{Self-examination and the Presbyterian diarist}

As literacy expanded thanks to the Presbyterian focus on basic schooling, the focus of diaries shifted from the purely confessional to ones which balanced the demands of secular life with religious commitment. In the seventeenth century the diary of a committed layman like Alexander Brodie makes barely any mention of secular affairs, which are mere asides from wrestling with spiritual matters (Brodie, 1863). Later, however, we have five diaries from devout laymen which indicate the purposes of diary keeping and the tensions that they reveal. These diaries spanned the years from the middle of the eighteenth century to the middle of the nineteenth. It is recognized that much of the context changed dramatically during this period. Indeed, a shift towards more secular themes, albeit in an enduringly spiritual context, 
will be seen in the following discussion. However, some features, such as the emphasis on accountability and recording for review, remained remarkably constant in these diaries.

George Brown was a Glasgow merchant, son of a church elder and bookseller. His diary ran from 1745 to 1753 and was printed for private circulation in the nineteenth century (Brown, 1856). Samuel Kevan was a master slater in London when he wrote his diary between 1798 and 1827 . He originally hailed from Wigton in south west Scotland and was a devout Presbyterian, although one who moved from sect to sect in London. His manuscript, preserved in the British Library, remains unpublished (but see Weeks, 2012 for a brief outline of his life). ${ }^{1}$ Adam Mackie was a farmer, merchant and innkeeper in the small Aberdeenshire village of Fyvie. His diary, later transcribed by a relative, covered the years 1818 to 1828 (Stevenson, 1991). Charles Cowan, whose diary has formed the basis for a consideration of the Protestant Ethic thesis, was a leading paper manufacturer in Penicuik, outside Edinburgh (McInstry and Ding, 2013). He was a church elder who left the Church of Scotland in the "Disruption" of 1843, when large numbers of ministers and laypeople formed the Free Church in opposition to the lay patronage of ministerial positions. His diary covers the periods 1833-36 and 1842-46. Finally, the diary of John Sturrock, a millwright in Dundee, is a rare example of a working class diary. Covering the years 1864-5, it was transcribed by a relative and later published (Whatley, 1996). Together, all our diarists were committed lay Presbyterians whose diaries provide a valuable insight into the tradition of self-examination laid down in sermons and devotional works.

Kevan, Mackie and Sturrock all give us explicit statements about their reasons for keeping a diary, which reflect the earlier injunctions. They suggest that a distinctive genre had emerged, where the common thread was a focus on recording activities for subsequent review and reflection. For Mackie, 
This book is purposed for writing down occurences, passing events and designed to serve as a refreshment of mind afterwards, and to be a sort of diary wherein I may write what manner I have spent my time whether in labour, study, business, pleasure or idleness. Also to be a taskmaster which I may suppose asks the question every night: What have you done this day? (emphasis in original) (Stevenson, 1991: 3)

This echoes Clark's injunction for frequent introspection. The diary was not to support occasional reflection, but ideally was to prompt on-going self-examination. Here we see a key distinction between the English Dissenting tradition represented by Joseph Ryder and the Scottish focus on accountability. Kadane notes "the absence of marginal notation of any kind in the diary's main pages, a silence that suggests that writing for the sake of devotional practice was more important to him than reading." By contrast, the Scottish diaries are replete with the language of accountability. For Kevan the purpose of diary keeping was to be "useful to myself for Humiliation, for Gratitude \& thankfulness."2 This involved using the diary for review. In January 1803, for example, he recorded "good part of forenoon looking over last years acct". ${ }^{3}$ In order to do this he added notes in the margin which acted as an index for speedy reference in a manner which was remarkably similar to the way in which registers of discipline were kept by Church of Scotland kirk sessions. As well as following this practice we know that in 1791 he had read Trail's work on the evidence for saving grace. ${ }^{4}$ Sturrock's diary was prompted by a particular event, his securing of employment at the Lilybank Foundry. His hours there were long, with his diary recording working days stretching to midnight as mills were fitted out. But the diary was not primarily to account for working time, but to be a record

of how I spend my leisure time, as much perhaps from curiousity as any other thing, but as I intend to keep a true and faithful record of how I spend and where I spend every evening, together with some of the more particular occurences of my daily life, 
also my correspondence, thoughts and feelings, and any particular mood or frame of mind I may be in, I may be able to form an estimate of how I have spent my leisure time, whether I have been trifling it away or turning it to any particular advantage (Whatley, 1996: 29).

Accounting for time was taken to its logical conclusion in Cowan's diary, where a pro-forma, printed by his own firm, was used to record the amount of time spent on business and spiritual matters, with the latter being split into personal and church affairs. A similar almost obsessive recording of time can be seen in the records kept by the ship designer David Kirkaldy whose time creating exquisitely detailed ships" drawing was recorded against categories down to quarter hours. His father was a Dundee merchant and shipper, elder at Cowgate, his mother the daughter of the most popular preacher in the town, the Reverend David Davidson (Scott, 1925: 322; Sage, 1889: 341, 409). This attention to detailed recording is paralleled by the focus of church bodies in maintaining extensive records of both decisions and financial transactions.

The diaries also record participation in, and reflection on, church matters, especially on sermons heard. Brown kept extensive notes on sermons which filled twelve quarto volumes (Brown, 1856: vii). He attended sermons at several different churches and recorded the reflections on the ones which most hit home. In October 1745, for example, he attended evening sermon at the Laigh Church which prompted the agonised reflection

O Lord, deliver me from an evil heart of unbelief, and an inordinate love of the world. Keep me from excessive desire of having worldly enjoyments continued with me, and from too much fear about lossing them. Let my care of my body be still subordinate to my care about my soul, and preserve me from sloathfullness (Brown, 1856: 4). 
In November 1825 the minister of Fyvie selected as his text a passage from Ecclesiastes, "Whatsoever Thy hand findeth to do, do it with all Thy might". He used this to deliver a homily on the moral worth of hard work, contrasting the value of manual labour to the indolence of the rich. Mackie thought that while, "the unconnectedness of the subject with religion appears out of place from the pulpit", the subject, "may be admitted on the score of harmonizing society in recommending habits of honest industry as a preparatory to that more blessed Society in Heaven to which we all aspire" (Stevenson, 1991: 40). As we will see below, this challenges any sense of a crude celebration of worldly success. Sturrock was also a keen sermon taster, on occasion attending three on the same Sunday. In December 1825 he recorded, "Got an excellent sermon from Mr Ewing, which he closed with the words, "Go to Christ this very night. Tomorrow may be too late." Most solemn words certainly if we could only keep them in our mind, but alas! the depravity of our hearts will not allow them to think of words so much to the point as these" (Whatley, 1996: 45). Such entries confirm the devout nature of our diarists and the process of constant self-examination that they felt obliged to engage in.

While some of the purpose of such recording was to prompt on-going review, it also supported a characteristic practice, that of the annual review at the end of the year. On the last day of 1746 George Brown lamented that he had slipped far below the standards he aspired to:

My predominants have been an inordinate love of worldly riches, and excess of affection to one I wanted to be settled in $\mathrm{m}-\mathrm{d}$ state in the world (with). These evils have led me to others, viz., wandring in duty, publick, private and secret, fretting and murmering at disappointments, joined with excessive wrath at the causes of these disappointments; but my leading sin has been pride and unbelief (Brown, 1856: 277). 
The importance of the diary was that it could show how time had been used. As John Sturrock wistfully noted on the last day of 1864, "Another year is now past. Another measure of time is gone. Gone forever beyond our reach and whether we have improved it or trifled it away there is now no remedy" (Whatley, 1996: 46). However, the end of year and its associated reflection could also provide a spur to do better in future. Kevan noted in January 1827 that "I have been trying to recount my many Sins \& failings - all in me aggravated in the highest degree. Many a time I have said both in public \& private that I was the Lords, yet as often in works deny him." As Adam Mackie observed at the beginning of 1827, "Now I pray God, who hath abundantly provided for me throughout life, may make this day to me the birthday of my soul, born again by the regenerating influence of Grace through Jesus Christ, that while diligent in business I may be fervent in spirit" (Stevenson, 1991: 39). What we note here is the balance between secular and spiritual affairs tilting, so that the annual review is not only of spiritual health, as in Brown's case, but of secular success. Mackie noted his business success at the beginning of 1825 but qualified it with

However it is all justly earned. I make a point in dealing fair with my customers and I find it is my interest to do so. I use every person civilly with little ceremony. I keep the best articles the price will afford, and my method of doing business is in selling is seldom to ask more than I take and in buying country produce I endeavour to ascertain the proper prices for the time and seldom offer less than is accepted. This method saves much time and argument and I succeed I may say to my wishes (Stevenson, 1991: 66).

This leads us towards the key tension in the diaries, that between secular and spiritual affairs, where we see that the rather glib assumption that Aho makes about the morality of the Protestant businessman is untenable. Brown, in particular, agonised frequently about worldly success. At the end of 1746 he worried that 
For some days my heart has been very fond of increase of wealth; Lord, impress my conscience with a sense of the threatenings of thy word against such as trust in riches, and say of gold, "thou art my hope" and thus deny the God that made them, that my desire this way be moderate, and regulated by the laws of the Gospell. This day heard Mr Kerr preach on the doctrine of justification, but found my heart very hard and vain in hearing. O deliver from a vain worldly mind! (Brown, 1856: 274).

One consequence was that such considerations had implications for the ways in which he ought to conduct his secular affairs:

in following one's worldly business, there is great need of grace, to teach and enable to do justice, live righteously, and speak the truth in heart, so as to have a conscience void of offence towards God and man. Unjustice, fraud, unrighteousness, dissimulation and lying, are evils flowing from an inordinate love of the world, and to which there are ensnaring and bewitching temptations in following people's worldly business (Brown, 1856: 303).

Brown was somebody who had attended university with the possibility of becoming a minister, so he may well have been more attuned to such concerns than our other diarists. However, Kevan also agonised about the snares of worldly success. In 1799, for example, he secured a contract to slate a building in Woodbridge, Suffolk. Part way through his contract he was joined by his wife and son and delighted in showing off the latter. This caused him to the sorrowful reflection that "the Day past in Lightness \& Vanity Pride \& folly". ${ }^{6}$ Kevan's slating business appears to have been successful (although there is little direct consideration of business success in the diary) but he was constantly on his guard against the temptations of such success. By contrast, one notes that secular affairs come more to the fore in the latter diaries, with Mackie, for example, using the year end to draw up more conventional balance 
sheets of business progress. However, these are always in the context of their subordination to spiritual matters. Over time the attributes of what it meant to be an adherent to the faith inevitably changed, but the commitment to self-examination, albeit against changing standards, remained. The agonising of Brown suggests that Aho's assertion is at the very least out of time, with sincere Protestant businessmen wresting with the legitimacy of their business affairs well into the eighteenth century. Changes in the nature of Presbyterianism, from an almost exclusive obsession with scriptural fidelity to broader issues of morality inevitably changed the emphasis of the diarists (McIntosh, 1998). It was the tradition of detailed recording and regular review which endured. We can see this in the observations of his biographer about Andrew Carnegie. Carnegie hailed from Dunfermline, a hotbed of radical Presbyterianism, in which successive secessions from the main Church of Scotland had shaken the roots of belief such that Carnegie rejected the faith of his forebears.

Nevertheless, Wall, notes

The end of the year for a Scottish Calvinist is a time for sober reflection, for pondering upon man's sinful frailty and God's awesome majesty. Carnegie had never accepted the Calvinist view of either man or God, but the ethos of Scotland had been bred into him. With all the introspection of an Edwards or a Knox, he took a hard, unpitying look at himself (Wall, 1970: 224).

This observation suggests the wider influence of the Scottish Presbyterian focus on selfexamination and detailed record keeping. It is these wider influences that we turn to next.

\section{Impacts}

Quite clearly, it is not being claimed that a full specification of Protestant pastoral power has been given here. Such a specification would need to explore the nature of lay participation in the pastorate, the public exercise of discipline and the approach to specifying governance 
systems to name just a few dimensions. However, the exploration of the traditions of selfexamination and record keeping shows both the value of extending Foucault's insights and some of their limitations. Indeed, looking at Reformed Protestantism can help us to turn back to some of Foucault's work with fresh eyes and recognise what was latent there. For example, it is surely significant that the first institution considered in the lineages of the modern prison is Amsterdam's Rasphuis of 1596, founded in one of the strongholds of Reformed Protestantism (Foucault, 1977: 120). Similarly, it would help us to see the genesis of Bentham's prison reforms in some of the traditions of Scottish political economy. It supports Gorski's (2005) emphasis on the need to look for the origins of the disciplinary revolution in both Calvinism and the Netherlands. This is a powerful corrective to accounts of Foucault's work that neglect these alternative sources, as well as misleadingly downplaying the impact of religion (Schwan and Shapiro, 2011: 103). It also provides an interesting parallel to the work in intellectual history of Israel with his focus on the contribution of the Netherlands and Spinoza to the Enlightenment (Israel, 2001). As we have noted, it also forms part of the context to the development of Samuel Smiles's Self Help, a book with considerable later resonance. However, what consideration of Protestant pastoral power might also help us to do is to return to some of Foucault's formulations with fresh eyes.

We have already noted that what seems to have prevented Foucault from delivering on the promissory notes he left about Protestant pastoral power was his turn to look for technologies of the self in classical antiquity. Here Seneca's practices for self-examination formed an important source. Foucault notes that

At least one example of self-examination, proposed by Chrysostom, was exactly the same form and the same administrative character as that described by Seneca in $D e$ Ira. In the morning, we must take account of our expenses, and in the evening we must ask ourselves to render account of our conduct of ourselves, to examine what is 
to our advantage and what if prejudicial against us, with prayers instead of indiscrete words. That is exactly the Senecan style of self-examination. It is also important to note that this self-examination is rare in Christian literature (Foucault, 1997: 245).

If we turn back to the work of James Clark and his guidance to the Glasgow merchants of the early eighteenth century, we find the following:

It would prove of great stead \& advantage to you everie day to examine yourselves; the ofter the better, for short counts make long Friends, ...; I cannot pass what Seneca says to this purpose, De Ira ..., "O what can be more pleasant than the dailie practice of self-examination" ... "O religious words from a Pagan! (Clark, 1703: 151).

Clark cites Seneca in other aspects of his work, suggesting that a focus on the confession gave Foucault a partial view of the Christian tradition. Let us pursue Seneca a little further. In 1783 a Glasgow merchant, Charles Hutcheson, attended a sermon in the little and rather ruinous church of Lamlash on the Isle of Arran. In rather disapproving tones he recorded that "The parson (a young fellow, \& Son of the present Incumbent) whose name is Stewart, gave us a 15 minutes discourse, which any body wou"d as soon have believed to be Senecas, as his, had they read it in a Book - Benevolence was the subject." (Hutcheson, 1919: 106). The disapproval might have related in part to the extreme shortness, in Scottish terms, of the sermon, but it also reflected a longstanding debate in Scotland between religious and "legal" preaching. That is, sermons which focussed just on morality were rather frowned upon by the faithful, who preferred an emphasis on the Scriptures. However, what this points to is a context in which some at least were keenly aware of both the Bible and of classical sources of moral guidance. So, in the library of the schoolmaster and church elder Andrew Rule of Glenmuick at about 1740 we find, amongst religious texts, Seneca's Morals (Rule 1740). 
Awareness of Seneca was thus part of the religious context to Smiles's advocacy of Self Help. (Matthews, 2004). His Self Help, published in 1859, was an immediate success, selling 20,000 copies in its first year. Smiles certainly knew his Seneca, observing in his book on Character that "Moses and David and Solomon, Plato and Socrates and Xenophon, Seneca and Cicero and Epictetus, still speak to us as from their tombs" (Smiles, 1876: 21). That was just a minor note in his work, but it was, as we have seen, part of the specifically Presbyterian tradition he hailed from. He was brought up in the "Anti-Burgher" Presbyterian church, a minority sect in Scotland where he endured a minister "preached the narrowest Calvinism." (Smiles, 2013: 27). Long after the practice had been given up in mainstream Scottish churches, offenders against church discipline were rebuked before the congregation. One distinguishing feature of Scottish Presbyterians was that, while they were prone to splitting over seemingly obscure points of theology, they adhered to the practices of governance that we have examined. Smiles, therefore, grew up in a context with the same emphases of selfexamination and accountability that we have been tracing. There were clearly other influences on his work, notably ideas of "self culture" drawn from the Boston Unitarian William Channing (Smiles, 1897). These are connections which deserve further explorations, but they are ones which suggest the value of returning to pastoral power in the Protestant tradition.

If the focus on the confessional provides a genealogy of modern techniques of governmentality such as therapeutic culture, then perhaps the contribution of Reformed Protestantism is in another stream of work, the self-help manual with its focus on improvement (Rimke, 2000). The Catholic tradition which so shaped Foucault, posited an "other", be that a confessor or a therapist, who could be involved in the self-monitoring of conduct (Carrette, 2000: 21). This then involved some form of relationship. By contrast, when Foucault turn to the ancients to look for technologies of the self his focus was on the 
Stoics, who attention was on self-control in a discipline that set the individual apart from others. Writing of the sixteenth century writer and politician Nicholas Bacon, Collinson observes that

He aspired above all to the Stoic ideal characterized by Erasmus as the quadratus homo, the foursquare man who is indifferent to worldly success and serene in the face of all adversity. This man was Seneca (Collinson, 1983: 139).

Here was a link in the genealogy of self-examination that is neglected by Foucault, but which comes to the fore when we consider the nature of Protestant pastoral power. This focus, which uses Stoic virtues in the service of spiritual self-examination, then becomes secularised in the celebration of thrift, education and hard work that marks nineteenth century versions. Given the powerful influence of varieties of Reformed Protestantism on the United States, in particular the influence of Scottish models of education and "common sense" philosophy, in addition to enduring anti-Catholic prejudice, it seems reasonable to suggest that the focus on individual self-improvement, as illustrated in self-help manuals, which is particularly strong in parts of the United States, owes at least something to this tradition (Wiebe, 1967: 4; Aspinwall, 1983: 43; Previs and Merino, 1997: 198). This seems to warrant further exploration of the nature of Protestant pastoral power and its powerful influence on modern conceptions of accountability.

References

Abend, Gabriel. (2014) The moral background : an inquiry into the history of business ethics, Princeton: Princeton University Press, 
Aho, James. (2005) Confession and bookkeeping: the religious, moral and rhetorical roots of modern accounting, Albany: State University of New York Press.

Aspinwall, Bernard. (1983) Portable utopia: Glasgow and the United States 1820-1920, Aberdeen: Aberdeen University Press.

Barrett, Edward. (2008) "The later Foucault in organization and management studies", Human Relations, 61(4), 515-537.

Brodie, Alexander. (1863) The diary of Alexander Brodie of Brodie 1652-1680 and of his son James Brodie of Brodie 1680-1685, Aberdeen: Spalding Club.

Brown, George. (1856) Diary of George Brown, merchant in Glasgow 1745-1753, Thomas Constable: Edinburgh.

Burchell, Graham, Gordon, Colin, and Miller, Peter. (1991) The Foucault effect : studies in governmentality : with two lectures by and an interview with Michel Foucault, Chicago: University of Chicago Press.

Carrette, Jeremy. (2000) Foucault and religion: spiritual corporality and political spirituality, London: Routledge.

Chatellier, Louis. (1989) The Europe of the devout: The Catholic Reformation and the formation of a new society, Cambridge: Cambridge University Press.

Clark, James. (1703) The spiritual merchant: or, the art of merchandizing spiritualized, Glasgow: Robert Sanders.

Collinson, Patrick. (1983) Godly people: essays on English Protestantism and Puritanism, London: Hambledon Press.

Foucault, Michel. (1991) Discipline and punish: the birth of the prison, London: Penguin. 
Foucault, Michel. (1997) Ethics, subjectivity and truth, (ed. Paul Rabinow, vol 1 of essential works), New York: The New Press.

Foucault, Michel. (1999) Abnormal: lectures at the Collège de France 1974-1975, New York: Picador.

Foucault, Michel. (2005) The hermeneutics of the subject: lectures at the College de France, New York: Palgrave Macmillan.

Foucault, Michel. (2009) Security, territory, population: lectures at the Collège de France 1977-1978, Basingstoke: Palgrave Macmillan.

Gerth, H., and Mills, C. W. (1948) From Max Weber: essays in sociology, London: Routledge \& Kegan Paul.

Gorski, Philip. (2003) The disciplinary revolution: Calvinism and the rise of the state in early modern Europe, Chicago: University of Chicago Press.

Hutcheson, Charles. (1919) “Journal to Arran in [Buteshire] Argyle-shire, [1783]”, Scottish Historical Review, 16, 94-131.

Israel, Jonathan. (2001) Radical enlightenment: philosophy and the making of modernity 1650-1750, Oxford: Oxford University Press.

Kadane, Matthew (2009) "Success and self-loathing in the life of an eighteenth-century entrepreneur" in Jacob, Margaret and Secretan, Catherine (Eds.) The self-perception of early modern capitalists, Basingstoke: Palgrave Macmillan, 253-271.

Kadane, Matthew (2013) The watchful clothier: The life of an eighteenth-century Protestant capitalist, New Haven: Yale University Press. 
MacCulloch, Diarmaid. (2004) Reformation: Europe's house divided 1490-1700, London: Penguin.

Macleod, Catriona and Durrheim, Kevin (2002) "Foucauldian Feminism: the Implications of Governmentality", Journal for the Theory of Social Behaviour 32(1), 41-60.

Matthews, H. C. G.. (2004) “Smiles, Samuel (1812-1904)”, Oxford Dictionary of National Biography, Oxford: Oxford University Press. [http://www.oxforddnb.com/view/article/36125, accessed 17 April 2014]

McInstry, Sam and Ding, Ying Yong, (2013) “Alex Cowan \& Sons Ltd, Papermakers, Penicuik: a Scottish case of Weber's Protestant Work Ethic", Business History, 55(5), 721739.

McIntosh, John. (1998) Church and theology in Enlightenment Scotland: the Popular Party 1740-1800, East Linton: Tuckwell.

Mennicken, Andrea and Miller, Peter. (2014) "Michael Foucault and the administering of lives" in Adler, Paul, Du Gay, Paul, Morgan, Glenn and Reed, Michael (eds.) The Oxford handbook of sociology, social theory \& organization studies, Oxford: Oxford University Press, 11-38.

Miller, Peter and Rose, Nikolas. (2008) Governing the present, Cambridge: Polity.

Mutch, Alistair (2009) "Weber and church governance: religious practice and economic activity”, Sociological Review, 57(4), 586-607.

Previs, Gary and Merino, Barbara. (1997) A history of accountancy in the United States, Columbus, Ohio: Ohio State University Press. 
Rimke, Heidi. (2000) “Governing citizens through self-help literature”, Cultural Studies, 14(1) 61-78.

Rule, Andrew (1740) Diary, 1720-1756, National Library of Scotland, Edinburgh, Adv.Ms.34.7.12.

Ryrie, Alec. (2006) The origins of the Scottish Reformation, Manchester: Manchester University Press.

Sage, Donald. (1889) Memorabilia domestica or parish life in the north of Scotland, Wick: W. Rae.

Schmidt, Leigh. (2001) Holy fairs: Scotland and the making of American revivalism, Grand Rapids, MI: Eerdmans Publishing Co.

Schwan, Anne and Shapiro, Stephen, (2011) How to read Foucault's Discipline and Punish, London: Pluto.

Scott, Hew. (1920) Fasti ecclesiae scoticanae; the succession of ministers in the Church of Scotland from the reformation. Volume 3, Synod of Glasgow and Ayr, Edinburgh: Oliver \& Boyd.

Scott, Hew. (1925) Fasti ecclesiae scoticanae; the succession of ministers in the Church of Scotland from the reformation. Volume 5: Synods of Fife and Angus and the Mearns, Edinburgh: Oliver \& Boyd.

Smiles, Samuel. (1876) Character, London: John Murray.

Smiles, Samuel. (1897 [1859]).Self-Help; with illustrations of character and conduct, London: John Murray. 
Smiles, Samuel. (2013 [1905]) The autobiography of Samuel Smiles, LLD, Cambridge:

Cambridge University Press.

Smout, T. (1982) "Born again at Cambuslang: new evidence on popular religion and literacy in eighteenth-century Scotland", Past \& Present, 97 114-127.

Stevenson, David. (1991) The diary of a canny man 1818-1828: Adam Mackie farmer, merchant and innkeeper in Fyvie, Aberdeen: Aberdeen University Press.

Trail, William. (1737) Some brief rules and directions concerning the great duty of selfexamination both before and after the Sacrament of the Lord's supper, Aberdeen: James Chalmers.

Wall, Joseph. (1970) Andrew Carnegie, New York: Oxford University Press.

Weatherhead, James. (1997) The constitution and laws of the Church of Scotland, Edinburgh: Church of Scotland.

Weber, Max. (1976) The Protestant ethic and the spirit of capitalism, London: Allen and Unwin.

White, Jerry. (2012) London in the eighteenth century: a great and monstrous thing, Bodley Head: London.

Whatley, Christopher. (1996) The Diary of John Sturrock, millwright, Dundee, 1864-65, East Linton: Tuckwell.

Wiebe, Robert. (1967) The Search for Order 1877-1920, Macmillan: London. 
${ }^{1}$ British Library (BL) Add MS 42556, autobiographical memoir and diary of Samuel Kevan (hereafter "Kevan").

${ }^{2}$ Kevan, i, 15 August 1829.

${ }^{3}$ Kevan, 107, 16 January 1803.

${ }^{4}$ Kevan, 24, 1791.

${ }^{5}$ Kevan, 411, 1 January 1827.

${ }^{6}$ Kevan, 67, 2 June 1799. 